\title{
Ten years of extracorporeal membrane oxygenation support at University Hospital Centre Zagreb
}

\section{(D)Mia Dubravčič*, DDubravka Šipuš, (DDora Fabijanović, (DHrvoje Jurin, DDaniel Lovrić, (D) Jure Samardžić, DDJana Ljubas Maček, DIvo Planinc, \\ DMarijan Pašalić, (D) Nina Jakuš, \\ (D)Maja Čikeš, \\ (DDavor Miličić, \\ (i)Boško Skorić}

University of Zagreb School of Medicine, University Hospital Centre Zagreb, Zagreb, Croatia

RECEIVED:

December 14, 2020

ACCEPTED:

December 18, 2020

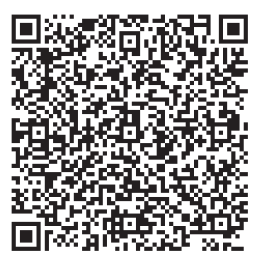

KEYWORDS: extracorporeal membrane oxygenation, survival, SAVE score, cardiopulmonary support. CITATION: Cardiol Croat. 2021;16(1-2):21-2. | https://doi.org/10.15836/ccar2021.21

*ADDRESS FOR CORRESPONDENCE: Mia Dubravčić, Klinički bolnički centar Zagreb, Kišpatićeva 12, HR-10000 Zagreb, Croatia. / Phone: +385-98-9549898 / E-mail: dubravcic.mia@gmail.com

ORCID: Mia Dubravčić, https://orcid.org/0000-0003-0441-4772 • Dubravka Šipuš, https://orcid.org/0000-0002-5631-0353 Dora Fabijanović, https://orcid.org/0000-0003-2633-3439 • Hrvoje Jurin, https://orcid.org/0000-0002-2599-553X Daniel Lovrić, https://orcid.org/0000-0002-5052-6559 • Jure Samardžić, https://orcid.org/0000-0002-9346-6402 Jana Ljubas Maček, https://orcid.org/0000-0001-7171-2206 • Ivo Planinc, https://orcid.org/0000-0003-0561-6704 Marijan Pašalić, https://orcid.org/0000-0002-3197-2190 • Nina Jakuš, https://orcid.org/0000-0001-7304-1127 Maja Čikeš, https://orcid.org/0000-0002-4772-5549 • Davor Miličić, https://orcid.org/0000-0001-9101-1570 Boško Skorić, https://orcid.org/0000-0001-5979-2346

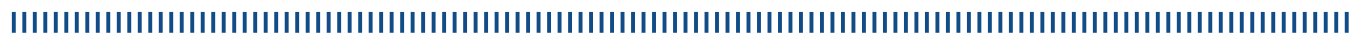

Background: Venoarterial extracorporeal membrane oxygenation (VA-ECMO) is increasingly used in patients during cardiac arrest and cardiogenic shock and is associated with increased survival rate ${ }^{1}$. Since mortality on ECMO is still rather high, SAVE (Survival after Veno-Arterial ECMO) score can be used to predict survival from refractory cardiogenic shock requiring ECMO².

Patients and Methods: We performed a retrospective analysis of 121 patients (78\% male) who underwent VA-ECMO implantation in our Department from January 2011 till November 2020 (Figure 1 and Table 1).

Results: Median age was 58 years with 21\% of patients older then 65 years. Median of ECMO duration was 6 days. The most common causes of cardiogenic shock were acute myocardial infarction and cardiomyopathy (53\% and 37\%, respectively) (Figure 2), and 37\% patients were implanted during cardiopulmonary resuscitation (eCPR). Overall survival on ECMO support was 59\%, but in patients after CPR only $34 \%$. Furthermore, of all patients, 34\% were successfuly weaned and the rest who survived continued on advanced heart failure therapies (Figure 3), but overall survival in follow-up was only $26 \%$. Median SAVE score was - 8 with significantly less negative values in patients younger than 65 and treated after 2015. Also, patients treated before 2015 had significantly higher values of creatinine, free hemoglobine and international normalized ratio (INR) and their survival rate was only $39 \%$, in comparison to those who were implanted after 2015 whose survival rate was $62 \%$.

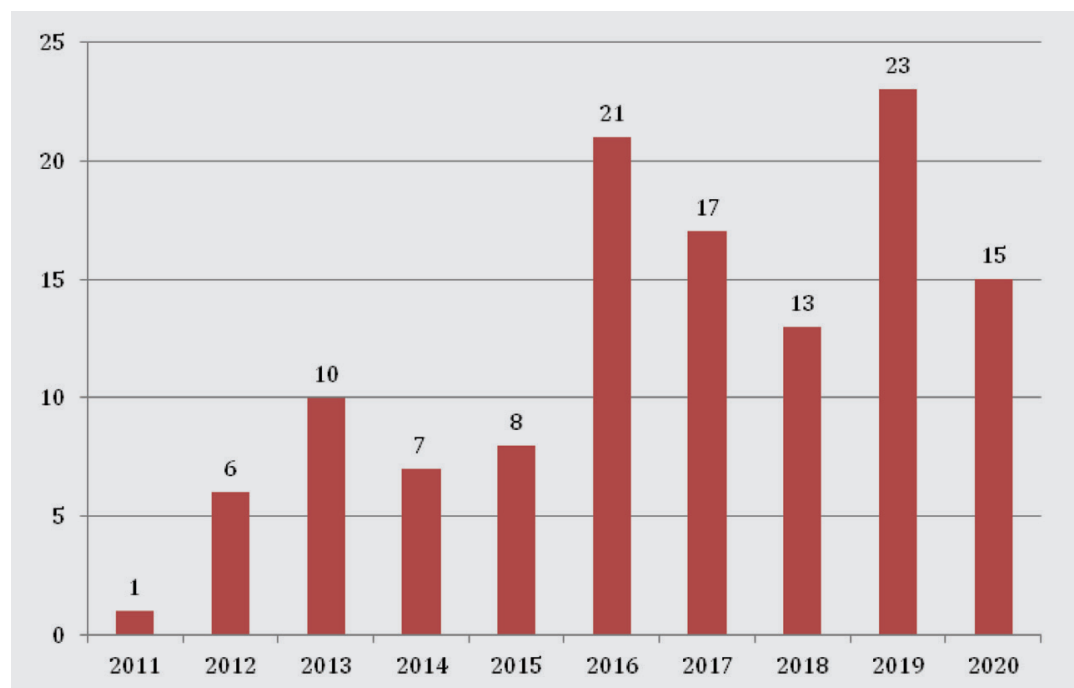

FIGURE 1. Number of venoarterial extracorporeal membrane oxygenation implantations from January 2011 to November 2020. 
TABLE 1. Clinical characteristics and laboratory values prior to venoarterial extracorporeal membrane oxygenation implantation.

\begin{tabular}{ll}
\hline Age, years (Mdn, IQR) & $58(49-64)$ \\
\hline Gender male (N, \%) & $94(78)$ \\
\hline BMI, kg/m² (Mdn, IQR) & $27(24-30)$ \\
\hline Creatinine, qmol/L (Mdn, IQR) & $130(87-173)$ \\
\hline Bilirubin, qmol/L (Mdn, IQR) & $16(10-34)$ \\
\hline INR (Mdn, IQR) & $1.2(1.05-1.52)$ \\
\hline NT-proBNP, ng/L (Mdn, IQR) & $7654(2834-15582)$ \\
\hline TnT, ng/L (Mdn, IQR) & $292(43-2620)$ \\
\hline LDH, U/L (Mdn, IQR) & $755(293-1817)$ \\
\hline CRP, mg/L (Mdn, IQR) & $20(4-74)$ \\
\hline SAVE score (Mdn, IQR) & $-8(-12--4)$ \\
\hline ECMO, days (Mdn, IQR) & $6(3-10)$ \\
\hline ECMO during CPR (N, \%) & $44(37)$ \\
\hline
\end{tabular}

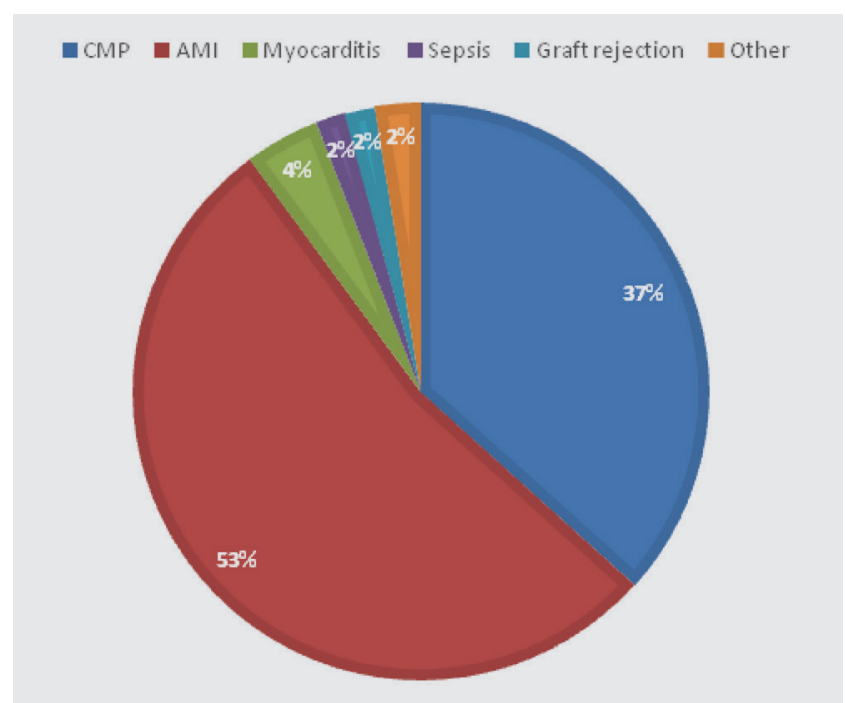

FIGURE 2. Etiology of cardiogenic shock.

CMP = cardiomyopathy; $\mathrm{AMI}$ = acute myocardial infarction

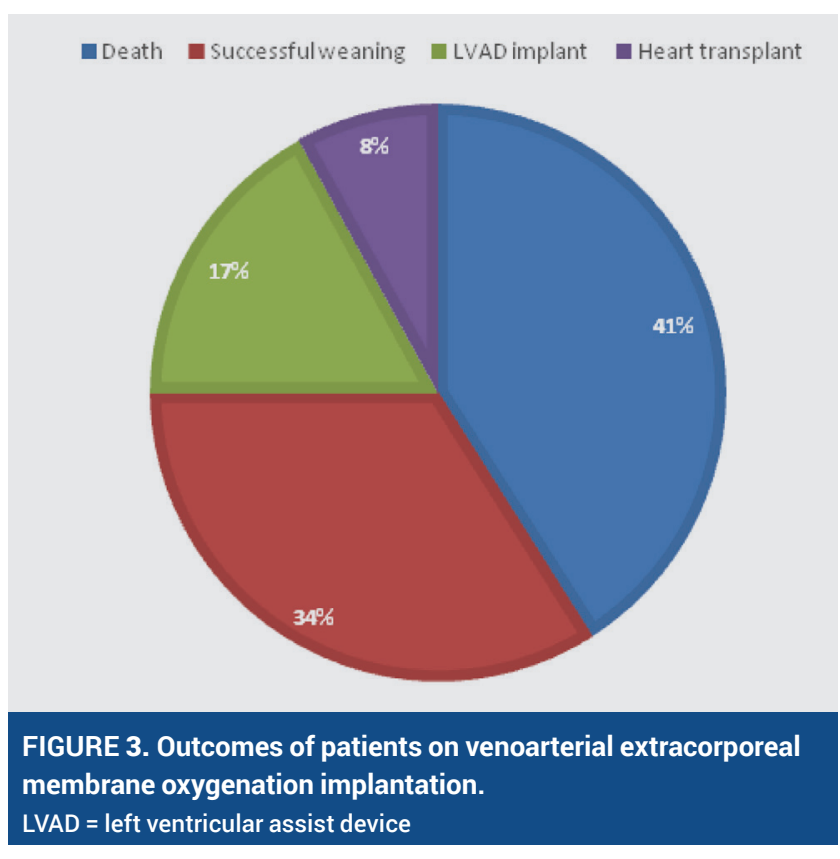

Conclusion: Although results with ECMO support in cardiogenic shock in our Department improved throughout 10-years experience, they still exhibit high long-term mortality. Our observations reinforce the need for thorough assessment of each ECMO candidate, especially in respect to patient's age, end-organ failure and SAVE score as key steps to ensure optimal outcomes.

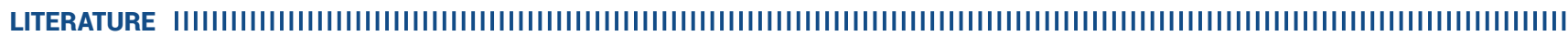

1. Ouweneel DM, Schotborgh JV, Limpens J, Sjauw KD, Engström AE, Lagrand WK, et al. Extracorporeal life support during cardiac arrest and cardiogenic shock: a systematic review and meta-analysis. Intensive Care Med. 2016 Dec;42(12):1922-1934. https://doi.org/10.1007/s00134-016-4536-8

2. Schmidt M, Burrell A, Roberts L, Bailey M, Sheldrake J, Rycus PT, et al. Predicting survival after ECMO for refractory cardiogenic shock: the survival after veno-arterial-ECMO (SAVE)score. Eur Heart J. 2015 Sep 1;36(33):2246-56. https://doi.org/10.1093/eurheartj/ehv194 